\title{
КРИМІНАЛІСТИЧНА ХАРАКТЕРИСТИКА КРИМІНАЛЬНИХ ПРАВОПОРУШЕНЬ, ПОВ'ЯЗАНИХ З УХИЛЕННЯМ ВІД СПЛАТИ МИТНИХ ПЛАТЕЖІВ
}

\begin{abstract}
Анотація. Стаття присвячена кримінальним правопорушенням, пов'язаним 3 ухиленням від сплати митних платежів. Запропоноване авторське розуміння криміналістичної характеристики кримінальних правопорушень, пов'язаних з ухиленням від сплати митних платежів. Виокремлено елементи структури криміналістичної характеристики кримінальних правопорушень, пов'язаних з ухиленням від сплати митних платежів. Охарактеризовано елементи криміналістичної характеристики кримінальних правопорушень, пов'язаних з ухиленням від сплати митних платежів. Визначено роль та місце криміналістичної характеристики під час розслідування кримінальних правопорушень, пов'язаних з ухиленням від сплати митних платежів.
\end{abstract}

Ключові слова: ухилення від сплати митних платежів, криміналістична характеристика, кримінальні правопорушення, розслідування, митний кордон, переміщення, товари.

Постановка проблеми. Визначальним елементом під час розслідування кримінальних правопорушень, пов'язаних 3 ухиленням від сплати митних платежів, $\epsilon$ криміналістична характеристика. Доцільність вивчення питання криміналістичної характеристики кримінальних правопорушень, пов'язаних з ухиленням від сплати митних платежів, зумовлена відсутністю в кримінально-правовій науці виокремлення цього різновиду кримінальних правопорушень, а також практичною необхідністю системного уявлення щодо об'єктивних і суб'єктивних ознак складів кримінальних правопорушень, пов'язаних з ухиленням від сплати митних платежів, з метою належної організації їх виявлення та розслідування.

Аналіз останніх досліджень і публікацій. Сутність криміналістичної характеристики, розробка криміналістичної характеристики різних видів кримінальних правопорушень були предметом дослідження в працях Ю.П. Аленіна, О.Я. Баєва, Р.С. Бєлкіна, В.П. Бахіна, А.Ф. Волобуєва, В.Г. Гавло, В.Г. Гончаренка, А.В. Іщенка, В.С. Кузьмічова, В.Г. Лукашевича, Є.Д. Лукьянчикова, Г.А. Матусовського, М.В. Салтевського та ін. Злочинні дії, пов'язані з ухиленням від сплати митних платежів, як правило, кваліфікуються як ухилення від сплати податків, зборів (обов'язкових платежів), оскільки ст. 212 КК України охоплює не тільки податки і збори, передбачені Податковим кодексом України, а і митні платежі, порядок сплати яких регламентовано як податковим, так і митним законодавством. Криміналістичній характеристиці ухилення від сплати податків, зборів (обов'язкових платежів) присвячені праці Р.С. Довбаша, О.С. Задорожнього, В.В. Лисенка, П.В. Цимбала, Г.Г. Філоненко. Однак криміналістична характеристика кримінальних правопорушень, пов'язаних з ухиленням від сплати митних платежів, не була предметом окремого дослідження.
Метою статті $є$ визначення поняття криміналістичної характеристики кримінальних правопорушень, пов'язаних 3 ухиленням від сплати митних платежів, та виокремлення іiі типових складових елементів.

Виклад основного матеріалу дослідження. 3'ясовуючи криміналістичну характеристику кримінальних правопорушень, пов'язаних з ухиленням від сплати митних платежів, слід звернути увагу на велике наукове і практичне значення криміналістичної характеристики, оскільки вона $є$ вірогідною моделлю конкретного кримінального правопорушення, дає змогу слідчому точніше оцінювати слідчу ситуацію, висувати слідчі версії, визначати напрями розслідування, цілеспрямовано збирати доказову інформацію, раціонально визначати комплекс першочергових слідчих дій та їх послідовність. Криміналістична характеристика слугує інформаційною базою для подальшої побудови методики розслідування, визначає раціональну систему побудови процесу розслідування окремих видів кримінальних правопорушень [1, с. 247].

Незважаючи на значну кількість наукових праць, присвячених сутності криміналістичної характеристики, варто відзначити, що до цього часу серед учених-криміналістів немає єдності поглядів стосовно поняття та структури криміналістичної характеристики. У дослідженнях науковців зміст категорії «криміналістична характеристика кримінальних правопорушень» тлумачиться як: модель типових ознак певного виду (групи) злочинів [2, с. 38]; система узагальнених даних (відомостей) про типові криміналістично значущі ознаки злочинів [3, с. 7-9]; наукове положення окремої методики розслідування, що є системою відомостей про елементи механізму злочину $[4$, c. 22]; наукова категорія, у якій описані типові ознаки і властивості події злочину [5, с. 17]; відправний елемент у структуpi окремих методик розслідування злочинів [6, с. 93]; ідеальна сукупність криміналістично значущих елементів та закономірностей скосння конкретного злочину [7, с. 5] тощо. Ці визначення вказують на різні аспекти криміналістичної характеристики кримінальних правопорушень 3 тими чи іншими редакційними особливостями. На наш погляд, найбільш прийнятною є позиція О.Н. Колесніченка та В.О. Коновалової, які визначають криміналістичну характеристику як систему відомостей (інформаціï) про криміналістично значущі ознаки кримінального правопорушення, що відображає закономірні зв'язки між ними і має призначення побудови та перевірки слідчих версій у розслідуванні конкретних кримінальних правопорушень [3, с. 16].

Не менш дискусійними $€$ також питання структури криміналістичної характеристики та кореляційних зв'язків між іiі елементами. Так, на думку О.Н. Колесніченко та В.О. Коновалова, до елементів криміналістичної характеристики для всіх 
злочинів належать: 1) спосіб злочину; 2) місце та обстановка скоєння злочину; 3) час скоєння злочину; 4) знаряддя та засоби скоєння злочину; 5) предмет злочинного посягання; 6) особа потерпілого; 7) особа, яка скоїла злочин; 8) сліди злочинного діяння [3, с. 22]. Своєю чергою М.В. Салтевський виділяє такі елементи криміналістичної характеристики: 1) предмет безпосереднього злочинного посягання; 2) спосіб скоєння злочину; 3) слідова картина; 4) особистість злочинця [8, с. 419]. Поряд 3 цим необхідно відзначити, що неможливо побудувати універсальну структуру криміналістичної характеристики, оскільки вона нерозривно пов'язана зі специфікою кожного виду (групи) кримінальних правопорушень. Для розробки криміналістичної характеристики кримінальних правопорушень, пов'язаних з ухиленням від сплати митних платежів, варто орієнтуватися на особливості цих кримінальних правопорушень.

Аналіз судових рішень по кримінальних правопорушеннях, пов'язаних з ухиленням від сплати митних платежів, дає змогу стверджувати, що основним кримінальним правопорушенням, пов'язаним з ухиленням від сплати митних платежів, є ухилення від сплати податків, зборів (обов'язкових платежів). При цьому слід враховувати, що злочин, передбачений у ст. 212 Кримінального кодексу України, пов'язаний з ухиленням від сплати митних платежів у разі, коли таке ухилення здійснюється із порушенням правил переміщення товару через митний кордон України. 3 огляду на те, що ухилення від сплати податків, зборів (обов'язкових платежів) за своєю правовою природою належить до економічних злочинів, доцільно навести криміналістичну характеристику економічних злочинів, запропоновану Г.А. Матусовським: 1) особа злочинця; 2) предмет злочинного посягання; 3) обстановка та умови скоєння злочину; 4) способи готування, скоєння та приховування злочину; 5) слідова картина [9, с. 58-60]. На думку В.В. Лисенко, в криміналістичній характеристиці ухилень від сплати податків найбільшого значення набувають такі іiі елементи: 1) способи підготовки, скоєння та приховування злочину; 2) особливості механізму утворення слідів; 3) характеристика особи злочинця [10, с. 13]. Натомість I.В. Александров стверджує, що основними елементами криміналістичної характеристики податкових злочинів є: дані про предмет злочинного посягання, час, місце й обстановку його скоєння; типові способи скоєння податкових злочинів; криміналістично значущі відомості про податкові злочини та сліди скоєння цих злочинів [11, с. 92].

Важливе місце в структурі криміналістичної характеристики кримінальних правопорушень, пов'язаних з ухиленням від сплати митних платежів, посідає предмет злочинного посягання. Предмет злочинного посягання - це матеріальні цінності (які людина може сприймати органами чуття чи фіксувати спеціальними технічними засобами), з приводу яких і шляхом безпосереднього впливу на які (або без нього) вчиняється злочинне діяння [12, с. 110]. Предмет злочинного посягання має принципове значення, оскільки корелюється з іншими його елементами. Зокрема, він пов'язаний з певними способами скоєння та приховування злочину та характеризує особу злочинця. Інформація про предмет злочину дає змогу скласти певне уявлення про особу злочинця, його відношення до процесу виробництва та відстежити злочинні зв'язки у злочинній групі, вказує на можливе коло свідків, які володіють чи можуть володіти необхідною інформацією для кримінального провадження [13, с. 71].
Обов'язковою умовою переміщення товарів через митний кордон України та розпорядження ними згідно iз заявленим режимом є сплата митних платежів. Згідно з п.п. 14.1.113 п. 14.1 ст. 14 Податкового кодексу України, митні платежі - це податки, що відповідно до цього Кодексу або митного законодавства справляються під час переміщення або у зв'язку з переміщенням товарів через митний кордон України, контроль за справлянням яких покладено на контролюючі органи [14]. Відповідно, предметом злочинного посягання у кримінальних правопорушеннях, пов'язаних 3 ухиленням від сплати митних платежів, є грошові кошти, які підлягають сплаті як митні платежі, що входять у систему оподаткування і введені у встановленому законом порядку. Ознаками грошових коштів, які є предметом злочинного посягання у кримінальних правопорушеннях, пов'язаних з ухиленням від сплати митних платежів, є: 1) грошові кошти у формі митних платежів, які не надійшли до державного бюджету; 2) такі грошові кошти мають бути у значних, великих та особливо великих розмірах, що встановлено приміткою до ст. 212 Кримінального кодексу України.

Значна роль належить таким елементам криміналістичної характеристики кримінальних правопорушень, пов'язаних з ухиленням від сплати митних платежів, як обстановка, час і місце скоєння цих злочинів. Під обстановкою скоєння злочину у криміналістичному аспекті слід розуміти систему певним чином взаємодіючих між собою в конкретних умовах місця і часу факторів об'єктивної реальності, що зумовлюють спрямованість і хід поведінки людей в події злочину, а також детермінуючий характер, механізм і умови матеріального відображення, процесів і явищ, що відбуваються у вигляді характерної, відносно стійкої (для однотипних злочинів) сукупності слідів, дослідження яких дає змогу судити про суть того, що відбулося [15, с. 16]. Основою обстановки кримінальних правопорушень, пов'язаних з ухиленням від сплати митних платежів, є встановлений порядок і правила переміщення товарів через митний кордон, територіально просторові чинники розташування митних кордонів, транспортних шляхів, населених пунктів, порядок митного оформлення та сплати митних платежів, форми й особливості здійснення митного контролю.

Крім цього, істотне значення в характеристиці обстановки кримінальних правопорушень, пов'язаних 3 ухиленням від сплати митних платежів, мають місце і час перетину митного кордону, а також місцезнаходження особи, що переміщує товар, оскільки саме від цих чинників залежить встановлення митним органом терміну і місця доставки та пред’явлення товарів для митного оформлення, строки декларування і сплати митних платежів. Дані про типові обставини, що сприяли ухиленню від сплати митних платежів, мають важливе прикладне значення для з'ясування способу вчинення таких кримінальних правопорушень, методів використання злочинцями конкретних умов 3 метою здійснення злочинних намірів.

Домінуючим елементом криміналістичної характеристики кримінальних правопорушень, пов'язаних з ухиленням від сплати митних платежів, є спосіб їх вчинення. Він охоплює систему взаємопов'язаних дій суб'єкта, що вчиняються 3 певною послідовністю, із застосуванням різних знарядь і засобів та спрямовані на досягнення мети злочину [16, с. 38]. Спосіб ухилення від сплати митних платежів можна визначити як сукупність дій винної особи, що спрямовані на умисну несплату передбачених митним та податковим законодавством митних платежів. Способи ухилення від сплати митних платежів 
можуть бути різними, але їх особливість полягає в тому, що злочинці передають органам державної фіскальної служби недостовірну інформацію щодо товарів, які переміщуються через митний кордон. У сукупності таких способів створюється схема обходу від сплати митних платежів, що впливає на сліди злочину, які виникають під час його скоєння. Інформація про спосіб ухилення від сплати митних платежів є основою для висунення версій, планування та організації розслідування, розробки заходів запобігання таким кримінальним правопорушенням.

Суттєве значення серед елементів криміналістичної характеристики кримінальних правопорушень, пов'язаних з ухиленням від сплати митних платежів, належить відомостям про особу злочинця. Це пов'язано $з$ тим, що головною фігурою у змісті злочинної діяльності є особа, яка скоює злочин. Поняття особи злочинця відображає сутність особи, яка скоїла злочин, тому може йтися про типові ознаки особи, схильної до скоєння того чи іншого виду злочину. Дані про типові мотиви злочину дають змогу окреслити в загальному потреби злочинця, що наштовхнули злочинця на скоєння злочину, i, як наслідок, встановити основні напрями розслідування [17, с. 258]. Вихідною криміналістичною ознакою особи злочинця виступає той факт, що така особа не виконує свій обов'язок щодо сплати митних платежів. Особою, на яку покладається обов'язок із сплати митних платежів, є декларант. Особою, на яку покладається обов'язок із сплати донарахованих митних платежів - податкового зобов' язання, визначеного за результатами документальної перевірки, є відповідний платник податків. Крім цих осіб, можуть бути інші особи, визначені в ст. 293 Митного кодексу України, на яких покладається обов'язок зі сплати митних платежів. У разі якщо відповідно до норм Митного кодексу України обов'язок зі сплати митних платежів покладається на кількох осіб, такі особи виконують зазначений обов'язок солідарно [18].

Результатом вчинення кримінальних правопорушень, пов'язаних 3 ухиленням від сплати митних платежів, є сліди скоєння цих злочинів. У сукупності вони утворюють «слідову картину» таких суспільно небезпечних діянь. У криміналістичній науці під слідами злочину розуміється частина інформації (матеріальної або ідеальної), що об'єктивно виникає в результаті злочину на всіх стадіях його скоєння, щодо якої є науково обгрунтовані, практично перевірені та допустимі засоби, прийоми й методи іiї виявлення, отримання, дослідження, використання та оцінки [19, с. 29-30]. Головними носіями інформації про ухилення від сплати митних платежів є документи (фінансові, бухгалтерські, податкові тощо) і лише вони містять основну «слідову картину» кримінальних правопорушень, пов'язаних з ухиленням від сплати митних платежів. Здебільшого у таких кримінальних правопорушеннях ці сліди є не підчистками, травленнями або іншими виправленнями подібного роду, а відносяться до групи інтелектуальних підроблень.

Висновки. Таким чином, розглянуті вище елементи криміналістичної характеристики кримінальних правопорушень, пов'язаних з ухиленням від сплати митних платежів, відображають найбільш характерні особливості цих злочинів. Криміналістична характеристика кримінальних правопорушень, пов'язаних 3 ухиленням від сплати митних платежів, - це система опису криміналістично значущих ознак цих злочинів, що відображає закономірні зв'язки між ними та має важливе організаційне і тактичне значення для виявлення та розслідування таких видів суспільно небезпечних діянь. До структури криміналістичної характеристики кримінальних правопору- шень, пов'язаних 3 ухиленням від сплати митних платежів, нами віднесено такі елементи, як предмет посягання, обстановка, час і місце скоєння цих злочинів, спосіб скоєння злочину, особа злочинця, слідова картина. Криміналістична характеристика злочинів має теоретичне та практичне значення для вирішення завдань методики розслідування кримінальних правопорушень, пов'язаних з ухиленням від сплати митних платежів.

\section{Jimepamypa:}

1. Місюра Н.М. Поняття криміналістичної характеристики злочинів та їі значення в методиці розслідування. Вісник Запорізького юридичного інституту Дніпропетровського державного університету внутрішніх справ. 2010. № 2. С. 242-248.

2. риминалистика: учебник / под ред. В.А. Образцова. М.,1997. 591 с.

3. Колесниченко А.Н., Коновалова В.Е. Криминалистическая характеристика преступлений: учебное пособие. Х.: Юрид. институт, $1985.92 \mathrm{c}$.

4. Волобуєв А.Ф. Наукові основи комплексної методики розслідування корисливих злочинів у сфері підприємництва: автореф. дис. ... д-ра юрид. наук: 12.00.09. Національна юридична академія України ім. Ярослава Мудрого. Х., 2002. 42 с.

5. Драпкин Л.Я. Предмет доказывания и криминалистические характеристики преступлений. Криминалистические характеристики в методике расследования преступлений: межвуз. сб. науч. тр. Свердловск, 1978. Вып. 69. С. 17-22.

6. Герасимов И.Ф. Криминалистические характеристики преступлений в методике расследования. Методика расследования преступлений: матер. науч.- практ. конф. М.: Всесоюз. координационное бюро по проблемам криминалистики, 1976. С. 93-96.

7. Гончаренко В.И. Понятие криминалистической характеристики преступлений. Криминалистика и судебная экспертиза. 1986. Вып. 33. С. 5-12.

8. Салтевський М.В. Криміналістика (у сучасному викладі): підручник. К: Кондор, 2006. 588 с.

9. Матусовский Г.А. Экономические преступления: криминалистический анализ. Харьков: Консум, 1999. 490 с.

10. Лисенко В.В., Задорожній О.С., Дзісяк О.П. Ухилення від сплати податків: виявлення та розслідування: монографія. К.: Істина, 2008. $216 \mathrm{c}$.

11. Александров И.В. Уклонение от уплаты налогов: основы криминалистической характеристики. СПб.: Издательство «Юридический центр-Пресс», 2011. 232 с.

12. Музика А.А. Предмет злочину: теоретичні основи пізнання: монографія. К.: ПАЛИВОДА А.В., 2011. 192 с.

13. Іванцова О.В. Криміналістична характеристика та особливості розслідування злочинів у галузі цукрового виробництва: дис. ... канд. юрид. наук: 12.00.09. Харківський національний університет внутрішніх справ Міністерства внутрішніх справ України. Х., 2018. $251 \mathrm{c}$.

14. Податковий кодекс України: Закон України від 2 грудня 2010 року № 2755-VI. Відомості Верховної Ради України. 2011. № 13-14, № 15-16, № 17. Ст. 112.

15. Винокуров С.И. Основные вопросы методики расследования преступных нарушений правил обращения со взрывчатыми материалами: автореф. дис. ... канд. юрид. наук: 12.00.09. М., 1967. 24 с.

16. Гора І. Поняття, спосіб вчинення злочину та його значення в розкритті та розслідуванні. Закон и жизнь. Международный научно-практический правовой журнал. 2012. № 9. С. 35-38.

17. Шепитько В.Ю. Криминалистика: курс лекций. Изд. 2-е, перераб. и доп. Харьков: Одиссей, 2005. 368 с.

18. Митний кодекс України: Закон України від 13 березня 2012 року № 4495-VI. Голос України. 2012. № 73-74 (5323-5324). С. 21-62.

19. Суворова Л.А. Идеальные следы в криминалистике. М.: Юрлитинформ, 2006. $200 \mathrm{c}$. 
Смолянинова Е. Я. Криминалистическая характеристика уголовных правонарушений, связанных с уклонением от уплаты таможенных платежей

Аннотация. Статья посвящена уголовным правонарушениям, связанным с уклонением от уплаты таможенных платежей. Предложено авторское понимание криминалистической характеристики уголовных правонарушений, связанных с уклонением от уплаты таможенных платежей. Выделены элементы структуры криминалистической характеристики уголовных правонарушений, связанных с уклонением от уплаты таможенных платежей. Охарактеризованы элементы криминалистической характеристики уголовных правонарушений, связанных с уклонением от уплаты таможенных платежей. Определены роль и место криминалистической характеристики при расследовании уголовных правонарушений, связанных с уклонением от уплаты таможенных платежей.

Ключевые слова: уклонение от уплаты таможенных платежей, криминалистическая характеристика, уголов- ные преступления, расследование, таможенная граница, перемещение, товары.

Smolyaninova O. Forensic characteristics of criminal offenses related to evasion of customs payments

Summary. The article is devoted to criminal offenses related to evasion of customs payments. The author's understanding of the forensic characteristics of criminal offenses related to evasion of customs payments is proposed. Elements of the structure of forensic characteristics of criminal offenses related to evasion of customs payments are highlighted. The elements of the forensic characteristics of criminal offenses related to evasion of customs payments are characterized. The role and place of forensic characterization in the investigation of criminal offenses related to evasion of customs payments has been determined.

Key words: evasion of customs payments, forensic characteristics, criminal offenses, investigation, customs border, relocation, goods. 